\title{
Effect of Tin Tailings on Some Refractory Properties of Alumino-Silicates (Alkaleri) Clay
}

\author{
Victor Sunday Aigbodion $^{1 *}$, Clement Uche Atuanya ${ }^{2}$, Chikaodi Cynthia Daniel-Mkpume $^{1}$ \\ ${ }^{1}$ Department of Metallurgical and Materials Engineering, University of Nigeria, Nsukka, Nigeria \\ ${ }^{2}$ Department of Metallurgical and Materials Engineering, Nnamdi Azikiwe University, Awka, Nigeria \\ Email: *aigbodionv@yahoo.com
}

Received October 4, 2012; revised November 27, 2012; accepted December 15, 2012

\begin{abstract}
The possibilities of upgrading some refractory properties of Alkaleri Clay (Alumino-silicates), found in Alkaleri Village, Bauchi State, Nigeria, by blending with tin tailings for the production of fireclay refractory bricks were investigated. Refractory properties such as: linear shrinkage, apparent porosity, bulk density, cold crushing strength and thermal shock resistance were tested with percentage additions of tin tailings from 5 - $30 \mathrm{wt} \%$ in the blend. The test was conducted using the standard test techniques in each case. The results were compared with standard refractory properties for fire clay bricks. Cold crushing strength, bulk density, refractoriness and thermal shock resistance of the bricks made from the blend clay increased, as the percentages of tin tailings increased. The Linear shrinkage and apparent porosity decreased as the percentages of tin tailings addition increased. All the values obtained from the blends are within the recommended values for dense fireclay bricks. Hence, dense fireclay can be produced from this blended.
\end{abstract}

Keywords: Tin Talings; Alkeri Clay; Refractory Properties

\section{Introduction}

Refractories are considered as inorganic materials, mainly of mixtures of oxides, obtained for naturally occurring minerals, which are capable of withstanding very high temperature condition, without any undue deformation, softening, change in composition, they include silica,magnetite, chrome, carbon, dolomite, alumino-silicates $[1,2]$. Most industries dealing with the treatment of ores and other materials for the manufacture of metallurgical, chemical and ceramic products operates at a very high temperature condition so, the equipment used for the treatment of this materials must sustain the operating temperatures and other working condition such as erosive and local conditions [3,4]. In the metallurgical industry, the most commonly used refractory include chromite, dolomite, magnetite, chrome magnesite, silica and alumino silicate clays $\left(\mathrm{Al}_{2} \mathrm{Si}_{2} \mathrm{O}_{5}\right)(\mathrm{OH})_{4}$. Others include fosterite, zircon refractories, zirconia refractories.

The properties of good refractories include [5];

- Resistance to thermal shock.

- Resistance to creep.

- High refractoriness under load.

- Low porosity and permeability.

- High volume stability.

- High refractoriness.

${ }^{*}$ Corresponding author.
Refractory which is widely used in the construction of furnaces, crucible etc. in metallurgical industries and in ceramic and chemical industries must be able to provide the properties listed above. Most refractory materials are made from naturally occurring high melting point oxides. They include silica $\left(\mathrm{SiO}_{2}\right)$, Alumina $\left(\mathrm{Al}_{2} \mathrm{O}_{3}\right)$, Magnesia $(\mathrm{MgO})$, Chromium oxide $\left(\mathrm{Cr}_{2} \mathrm{O}_{3}\right)$, Zirconia $(\mathrm{ZrO})$ and iron oxide. They are either used in natural form without any formal processing or in roasted condition. They are also used in synthetic form comprising many artificial prepared refractories [6].

Tin Tailings are the waste portions of mined material that are separated from the target mineral(s) during beneficiation. By far the larger proportion of tin ore mined in most industry sectors ultimately becomes tailings that must be disposed. In the tin industry, for example, only a few hundredths of an ounce of tin may be produced of every ton of dry tailings generated. Similarly, the copper industry typically mines relatively low-grade ores that contain a low percent of metal values; the residue becomes tailings. Thus, tailing disposal is a significant portion of the overall waste management practice at mining and milling operations [7].

Earlier works on Alkaleri Clay (Alumino-Silicate) deposit showed that it has low spalling resistance and high apparent porosity [8], which is not satisfactory, hence there is need, to improve the refractory properties of this 
clay. It is the light of the foregoing that the research on the investigation of the effects of tin tailings on some refractory properties of Alkaleri clay was motivated.

\section{Experimental Procedures}

\subsection{Collection of Clay Samples}

As-mind samples of Alkaleri (Bauchi clay) and the tin tailings were collected from the stockyard of the refractory department of the National Metallurgical Development Center, Jos, Nigeria. The average size of the samples was between $20-30 \mathrm{~cm}$. Table 1 showed the composition of the clay [2] and Table 2 show chemical composition of Jos tin tailings [9].

\subsection{Preparation of the Clay}

The raw clay was soaked in water for three days and dried in open air for a week, this treatment was necessary to remove alkalis, and some dead organic matters. The presence of alkalis, sodium and potassium, retard mullite formation and hence lowers the refractoriness and strength of the clay [6]. The dried clay was then crushed and ground into powder form using jaw crushers and pulverizing machine. The ground clay was sieved to pass through sieve 300 um aperture

\subsection{Brick Production}

Preparation of the test samples involved mixing of the freshly sieved clay with varied percentage of tin tailings between $5 \%$ - 230\%. The clay mixture was found to be plastic at $10 \%$ water content level. The mixed blend was packed into a metal moulding box and pressed using hydraulic press. A pressure of $15 \mathrm{~kg} / \mathrm{cm}^{2}$ was applied to enhance homogeneity and surface smoothness of the samples.

The mould bricks were dried in open air for three days, followed by drying in oven for 12 hours at $110^{\circ} \mathrm{C}$ to ex- pel any moisture left in the bricks and to avoid crack during firing. Firing was carried out in electric heating furnace pre set at heating rate of $7^{\circ} \mathrm{C} /$ minute. The firing procedure used involved heating and soaking the samples at various temperatures that is: $250^{\circ} \mathrm{C}$ for 6 hours, $650^{\circ} \mathrm{C}$ hours for 4 hours, $950^{\circ} \mathrm{C}$ for 3 hours, $1100^{\circ} \mathrm{C}$ hours for 8 hours and $1600^{\circ} \mathrm{C}$ hours for 8 hours. After firing the bricks were then allowed to cool in the furnace at a cooling rate of $1^{\circ} \mathrm{C} /$ minute [6].

\subsection{Test Procedure}

The fired bricks were tested for linear shrinkage, apparent porosity, bulk density, cold crushing strength and thermal shock resistance according to the recommended standard.

\subsubsection{Linear Shrinkage}

The green and fired dimensions of the bricks were measured and record using veniar caliper. The linear shrinkage was then calculated as a percentage of the original wet length as shown below [3]:

Percentage of fried shrinkage $=\frac{l_{b}-l_{c}}{l_{b}} \times 100(\%)$

$l_{b}$-dimension of green bricks,

$l_{c}$-dimension of fired bricks.

\subsubsection{Apparent Porosity and Bulk Density}

The fried brick was kept in the oven at $110^{\circ} \mathrm{C}$ for 3 hours to obtained constant weight $D$ the brick was then suspend in distilled water and boiled on a hot plate for 30 minutes, after boiling, while still in hot water, the water was now displaced with cold water and the weight $W$ was measured on a spring balance hinged on the a tripod stand. The test samples were removed from the water and extra water wiped off from the surface by lightly blotting the sample with wet towel and the weight $S$ in air was measured, the apparent porosity $\left(P_{a}\right)$ of the bricks was de-

Table 1. Chemical compositions of Alkaleri Clay.

\begin{tabular}{|c|c|c|c|c|c|c|c|c|c|c|}
\hline \multirow{2}{*}{ Refractories } & \multicolumn{10}{|c|}{ Chemical Compositions ( \% ) } \\
\hline & $\mathrm{SiO}_{2}$ & $\mathrm{Al}_{2} \mathrm{O}_{3}$ & $\mathrm{Fe}_{2} \mathrm{O}_{3}$ & $\mathrm{CaO}$ & $\mathrm{MgO}$ & $\mathrm{Na}_{2} \mathrm{O}$ & $\mathrm{K}_{2} \mathrm{O}$ & $\mathrm{ZrO}_{2}$ & $\mathrm{TiO}_{2}$ & L.O.I \\
\hline
\end{tabular}

Table 2. Chemical composition of jos tin tailings.

\begin{tabular}{|c|c|c|c|c|c|c|c|c|c|c|c|c|c|}
\hline Compound & $\mathrm{Si} \mathrm{SiO}_{2}$ & $\mathrm{Ca} \mathrm{CaO}$ & $\mathrm{Ti} \mathrm{TiO}_{2}$ & $\mathrm{~V} \mathrm{~V} \mathrm{~V}_{2} \mathrm{O}_{5}$ & $\mathrm{Cr} \mathrm{Cr}_{2} \mathrm{O}_{3}$ & $\mathrm{Mn} \mathrm{MnO}$ & $\mathrm{Fe} \mathrm{Fe}_{2} \mathrm{O}_{3}$ & $\mathrm{Ni} \mathrm{NiO}$ & As $\mathrm{As}_{2} \mathrm{O}_{3}$ & $\mathrm{Y} \mathrm{Y}_{2} \mathrm{O}_{3}$ & $\mathrm{Zr} \mathrm{ZrO}_{2}$ & $\mathrm{Nb} \mathrm{Nb} \mathrm{O}_{5}$ & $\mathrm{Ag} \mathrm{Ag}_{2} \mathrm{O}$ \\
\hline$\%$ & 11 & 0.25 & 1.2 & 0.07 & 0.23 & 0.29 & 4.75 & 0.03 & 0.00 & 0.790 & 68.7 & 1.57 & 1.4 \\
\hline \multicolumn{2}{|c|}{ Channel Compound } & $\mathrm{Sn} \mathrm{SnC}$ & \multicolumn{2}{|c|}{$\mathrm{Ba} \mathrm{BaO}$} & $\mathrm{uu} \mathrm{EuO}_{3}$ & 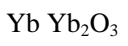 & \multicolumn{2}{|c|}{ Hf $\mathrm{HFO}_{2}$} & $\mathrm{a} \mathrm{Ta}_{2} \mathrm{O}_{5}$ & $\mathrm{Au} \mathrm{Au}$ & $\mathrm{Pb} \mathrm{PbO}$ & $\mathrm{Th} \mathrm{ThO}_{2}$ & $\mathrm{U} \mathrm{U}_{3} \mathrm{O}_{8}$ \\
\hline \multicolumn{2}{|c|}{$\begin{array}{l}\text { Concentration } \\
\text { Unit (\%) }\end{array}$} & 0.64 & \multicolumn{2}{|c|}{0.53} & 0.001 & 0.45 & \multicolumn{2}{|c|}{0.84} & 0.31 & 0.10 & 0.13 & 0.78 & 0.45 \\
\hline
\end{tabular}


termined from the relationship [1].

$$
P_{a}=\frac{W-D}{W-S} \times 100(\%)
$$

$P_{a}=$ apparent porosity

The Bulk density $\left(B_{d}\right)$ was also calculated from the relationship as [8]

$$
B_{d}=\frac{D}{W-S}\left(\mathrm{~g} / \mathrm{cm}^{3}\right)
$$

$B_{d}=$ bulk density, $D=$ Dried weight, $W=$ Soaked weight, $S=$ Suspended weight

\subsubsection{Cold Crushing Strength}

The fried bricks were tested for crushing strength using hydraulic strength testing machine. The crushing strength was then calculated using the relationship [2]:

$$
\text { Cold Crushing strength }=\frac{\operatorname{load}(\mathrm{KN})}{\operatorname{Area}\left(\mathrm{m}^{2}\right)}
$$

\subsubsection{Thermal Shock Resistance}

A thermal shock resistance test samples were put in furnace that was maintained at a temperature of $1300^{\circ} \mathrm{C}$ and soaked at this temperature for 30 minutes after this the brick was brought out to cool for 10 minutes. The brick was then tested for failure using a standard rig, if failure did not occur the brick was then put back inside the furnace and heated for a period of ten minutes, this cycle of heating, cooling and testing was repeated Until failure occurred. The number of complete cycles to produce failure in each sample was noted.

\section{Results and Discussion}

\subsection{Firing Shrinkage of Tin Tailings}

The firing shrinkage value increases with increasing tin tailings. The fire shrinkage of $3.6 \%$ and $1.0 \%$ were obtained at $0 \mathrm{wt} \%$ and $30 \mathrm{wt} \%$ tin tailing additions. This value is adequate for refractory production [2] (Figure 1). This means that tin tailings does burnt off during firing.

\subsection{Apparent Porosity of Tin Tailings}

The apparent porosity of the bricks decreases as the percentage of tailings decreased (see Figure 2). The apparent porosity value of $39.45 \%$ for $0 \mathrm{wt} \%$ is greater than that of the recommended value of $22-25$ for medium heat duty 23 - 26 for high heat duty fire clay refractory.

\subsection{Bulk Density}

Bulk density of the refractory bricks increases with increasing tin tailings. The bulk density of $1.90-2.30$ $\mathrm{g} / \mathrm{cm}^{3}$ for fireclay is less than that obtain for the tin tailing bricks [9] (see Figure 3).

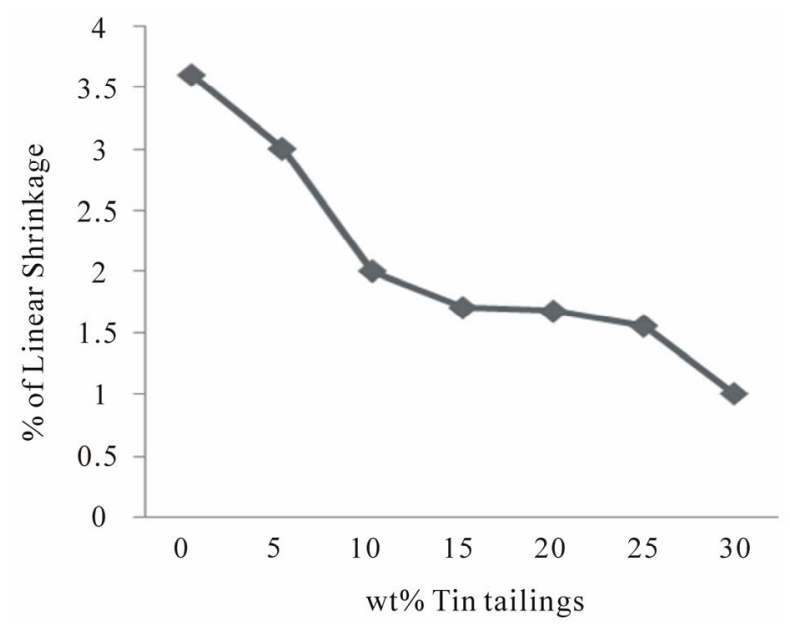

Figure 1. Variation of $\%$ of linear shrinkage with wt $\%$ tin tailings.

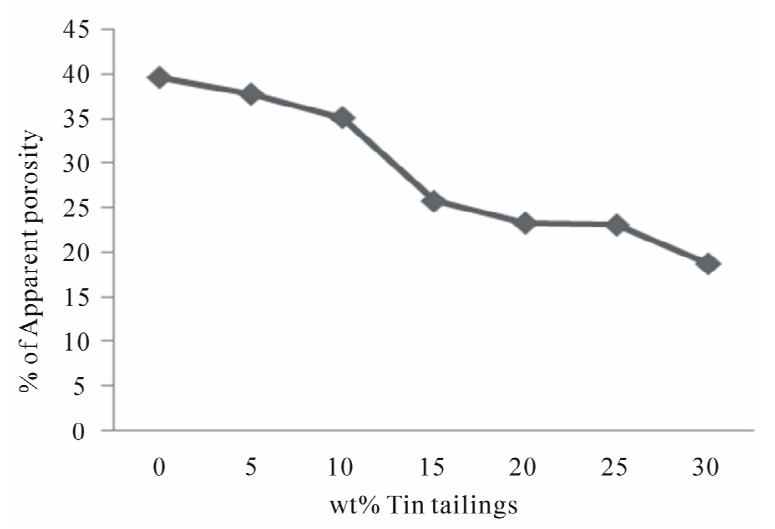

Figure 2. Variation of \% of apparent porosity with wt\% tin tailings.

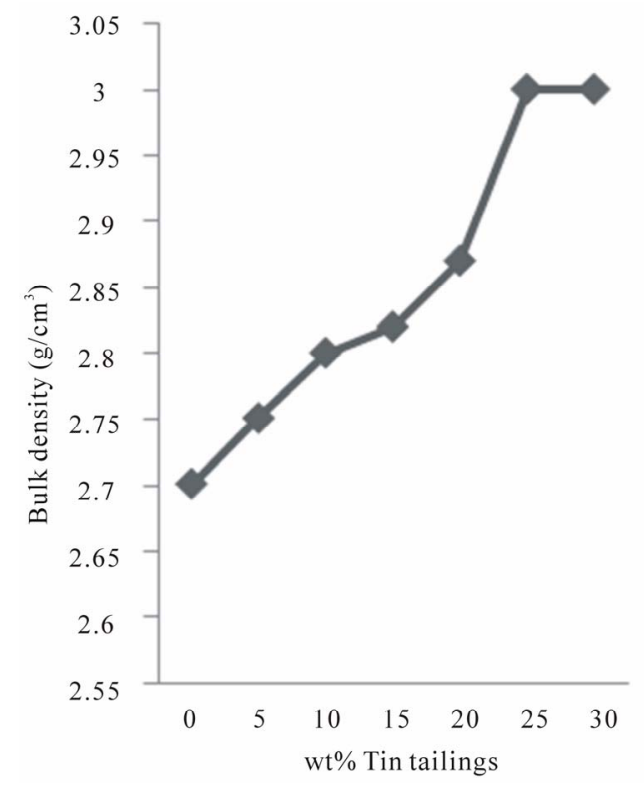

Figure 3. Variation of bulk density with wt $\%$ tin tailings. 


\subsection{Cold Crushing Strength}

The cold crushing strength as shown in Figure $\mathbf{4}$ increases with increasing tin tailings. The cold crushing strength value for all the blended corresponds to the standard values of Indian fireclay refractory of 250 - 300 $\mathrm{kg} / \mathrm{cm}^{2}$ for super heat duty 1 and 400 - 600 for super heat duty 2. The values obtained for all the sieve sizes are high enough for a refractory material and is accounted for good bonding and vitrification during firing [9].

\subsection{Thermal Shock Resistance}

The thermal shock resistance of the bricks increases as the percentage of tin tailings. The thermal shock resistance is poor as the $10 \%-15 \%$ tin tailings. The thermal shock resistance of the bricks increases to 22 cycles at 30 wt $\%$ tin tailings, this blend falls within the accepted range of 15+ cycles [1-7] (see Figure 5).

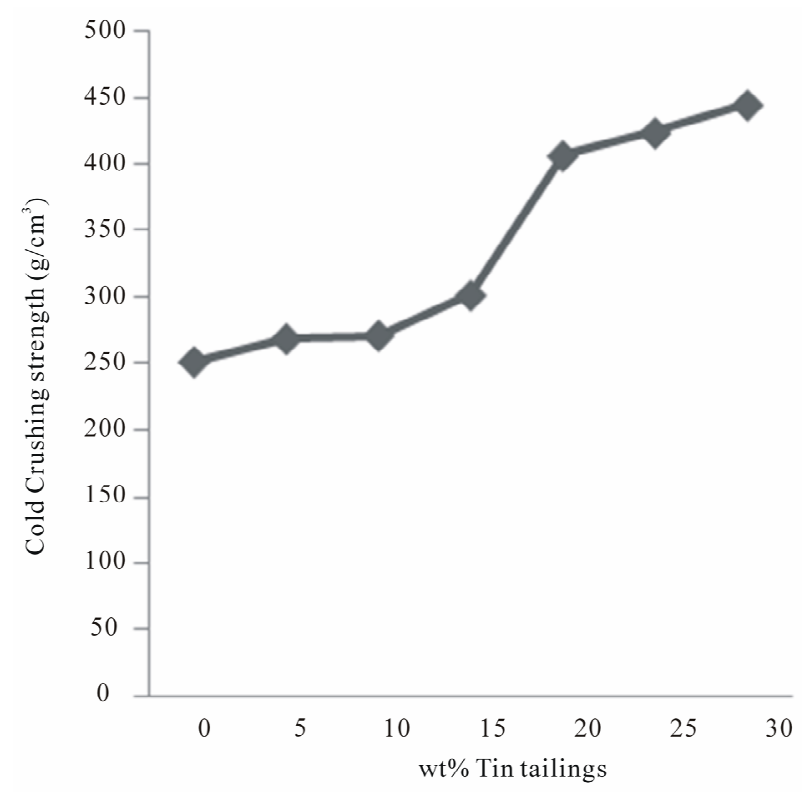

Figure 4. Variation of cold crushing strength with wt\% tin tailings.

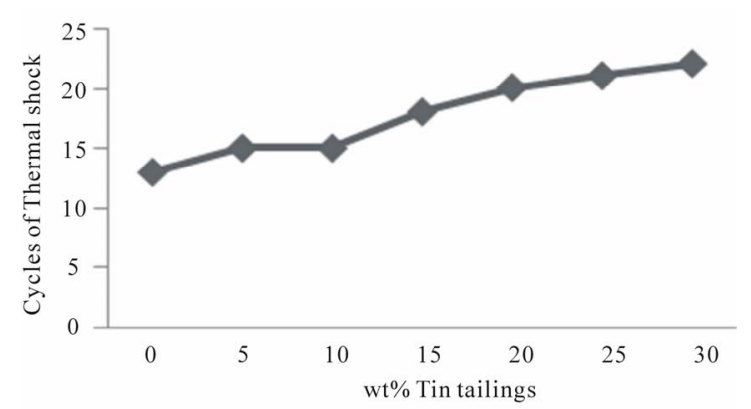

Figure 5. Variation of cycles of thermal shock with wt $\%$ tin tailings

\section{Conclusions}

From the results of the research carried out on Tin tailing an industrial waste from the mineral processing industry as a reinforced of Alkaleri Caly for refractory bricks production, based on the outcomes the following conclusions can be made:

1) The increase in cold crushing strength as the weight percentage of tin tailings shows that high strength bricks can be made from this blended.

2) The refractory brick made with $30 \mathrm{wt} \%$ tin tailings has the lowest value of firing shrinkage, porosity and with acceptable value of thermal shock resistance. This implies that good refractory brick can be produced with this composition.

3) This bricks has refractory properties which can be compared favourably with Indian fire clay refractory.

4) This bricks can be employed in refractory bricks production for furnace lining.

\section{REFERENCES}

[1] A. R. Chesti, "Refractories Manufacture, Properties and Application,” Prentice Hall of Private Limited, London, 1986, pp. 1-140.

[2] S. B. Hassan, "Refractory Properties of Bauchi and Onibode Clay of Nigeria for Furnace Lining," African Journal of Sciences and Technology, Vol. 1 No. 1, 2000, pp. 56-60.

[3] J. H. Chesters, "Refractory Production and Properties," The Iron and Steel Institute, London, 1975, pp. 295-315.

[4] J. U. Omuwomi, "Characterisation of Some Nigerian Clay Deposits as Refractory Materials for Furnace Lining,” Nigerian Journal of Engineering Materials, Vol. 2, No. 3, 2001, pp. 34-40.

[5] V. S. Aigbodion, "An Investigation of the Effect of Ile-Oluji Clay on Some Refractory Properties of Alkaleri Clay, Insights on Science and Technology," Afro-Euro Centre for Development Studies, Sprain, 2008, pp. 21-29.

[6] V. S. Aigbodion, A. S. A. Rahman and I. A. Madugu, "Characterisation Study of the Effect of Zircon Sand on Some Refractory Properties of Alkaleri Clay,” International Research Journal in Engineering, Science and Engineering, Vol. 4 No. 2, 2007, pp. 135-142.

[7] S. B. Hassan, "The Study of the Refractory Properties of Some Nigerian Clay Deposits,” Master's Thesis, Department of Metallurgical Engineering, Ahmadu Bello University, Zaria, 1990, pp. 23-40

[8] Jos Tin Smelting Company, 2006. www.amanaonline.com

[9] E. O. Akinbode, "An Investigation on the Properties of Termite Hill as Refractory Material for Furnace Lining," Indian Foundry Journal, Vol. 5, No. 3, 1996, pp. 10-13 